\title{
Neuroprotective efficacy of ABCA1 and HDL in aging rats with cerebrovascular hypoperfusion
}

\author{
Linhui Wang ${ }^{1,2,3}$, Mingyuan Tian ${ }^{1,2,3}$, Gang Yu ${ }^{4}$, Hongchi Luo ${ }^{1}$, Yu Li $1^{1,2,3^{*}}$ \\ From 2011 International Conference on Molecular Neurodegeneration \\ Shanghai, China. 22-24 September 2011
}

\section{Background}

To establish an animal model of Vascular dementia(VD), which produced by permanent, bilateral occlusion of the common carotid arteries $(2 \mathrm{VO})$ in aging rats, and to study the expression of ABCA1 protein in hippocampal CA1 and the levels of serum HDL and TC in a vascular dementia model.

\section{Method}

Brain hypoperfusion was induced by $2 \mathrm{VO}$. Dynamic changes of $\mathrm{ABCA} 1$ in hippocampus were detected by immunohistochemistry. Serum levels of HDL and TC in different groups of rats were measured by automatic biochemical analyzer.

\section{Result}

The levels of serum HDL and TC increased at 2 weeks post-surgery compared with sham-operated group $(\mathrm{P}<0.05)$. Then, the levels decreased to the lowest at 4 weeks accompanied by the prolonged ischemia compared with 2 weeks post-surgery $(\mathrm{P}<0.05)$. However, the expression of ABCA1 showed significant difference in the CA1 of hippocampus at 1 week after $2 \mathrm{VO}$ compared with sham-operated group $(\mathrm{P}<0.05)$. It slightly increased accompanied by recovery of cerebral blood flow (CBF) at 2 weeks compared with sham-operated group $(\mathrm{P}>0.05)$. The expression of $A B C A 1$ reached to the peak at 3 weeks $(\mathrm{P}<0.01)$. At 4 weeks, the expression of $\mathrm{ABCA} 1$ began to decrease, it showed significant different compared with sham-operated $(\mathrm{P}<0.01)$.

\section{Conclusion}

We demonstrated that ABCA1 and HDL underwent dynamic expression in hippocampus of rats' brain after

'Department of Pathology, Chongqing Medical University, Chongqing 400016, China

Full list of author information is available at the end of the article
2VO. It suggested that ABCA1 and HDL might play protective roles in vascular dementia. Our study gave further evidence for clarifying the underlying mechanism of Lipid metabolism in vascular dementia, but more data are needed to firmly confirm this protective effect.

\section{Acknowledgements}

This study was supported by Program for Excellent talent in University of Chongqing (2010).

\section{Author details}

'Department of Pathology, Chongqing Medical University, Chongqing 400016, China. ${ }^{2}$ Institute of Neuroscience, Chongqing Medical University, Chongqing 400016, China. ${ }^{3}$ Chongqing Key Laboratory of Neurobiology, Chongqing Medical University, Chongqing 400016, China. ${ }^{4}$ Department of Neurology, the First Affiliated Hospital, Chongqing Medical University, Chongqing 400016, China.

Published: 7 February 2012

doi:10.1186/1750-1326-7-S1-S2

Cite this article as: Wang et al:: Neuroprotective efficacy of ABCA1 and $\mathrm{HDL}$ in aging rats with cerebrovascular hypoperfusion. Molecular Neurodegeneration 2012 7(Suppl 1):S2.

Submit your next manuscript to BioMed Central and take full advantage of:

- Convenient online submission

- Thorough peer review

- No space constraints or color figure charges

- Immediate publication on acceptance

- Inclusion in PubMed, CAS, Scopus and Google Scholar

- Research which is freely available for redistribution

\section{() Biomed Central}

(c) 2012 Wang et al; licensee BioMed Central Ltd. This is an Open Access article distributed under the terms of the Creative Commons Attribution License (http://creativecommons.org/licenses/by/2.0), which permits unrestricted use, distribution, and reproduction in any medium, provided the original work is properly cited. 